\title{
Self-efficacy, Job Design, and Work Motivation on Work Effectiveness of Lecturer at Institute Transportation and Logistics Trisakti Jakarta
}

\author{
Johar $^{1}$, Maruf Akbar ${ }^{2}$, Neti Karnati ${ }^{3}$ \\ \{joharsamosir@yahoo.co.id ${ }^{1}$, maruf.akbar@unj.ac.id ${ }^{2}$, neti.karnati@unj.ac.id $^{3}$ \}
}

\begin{abstract}
${ }^{1} \mathrm{PhD}$ Student of Education Management Department, Universitas Negeri Jakarta Indonesia, Jl. Rawamangun Muka Pulo Gadung, Jakarta Timur, Daerah Khusus Ibu Kota Jakarta 13220, Indonesia

${ }^{2,3}$ Education Department Management, Universitas Negeri Jakarta , Jl. Rawamangun Muka Pulo Gadung, Jakarta Timur, Daerah Khusus Ibu Kota Jakarta 13220, Indonesia
\end{abstract}

\begin{abstract}
The objective of this research was to determine the effect of self-efficacy, job design, and work motivation on work effectiveness of lecturer at Institut Transportasi and Logistik Trisakti Jakarta. The research was conducted by using a survey method with path analysis applied in testing hypothesis. The target population size of this research is 122 of lectures. Research samples selected as much as 93 lectures using simple random sampling technique. Based on this research of data obtained the following conclusions: (1) the self-efficacy has positive direct effect to work effectiveness, (2) the job design has positive direct effect to work effectiveness, (3) work motivation has positive direct effect to work effectiveness, (4) the self-efficacy has positive direct effect to work motivation, (5) the job design has positive direct effect to work motivation. The conclusion is that the lecture's work effectiveness is effected by the self-efficacy, job design, and lecturer's work motivation.
\end{abstract}

Keywords: Work Effectiveness, Self-Efficacy, Job Design, and Work Motivation

\section{Introduction}

Lecturer is one of the educational staff who has a role as one of the determinants of the success of educational goals, because lecturers are directly in contact with students, to provide guidance that will produce the expected graduates [1]. Lecturers are human resources who become planners, actors and determinants of achieving organizational goals. Lecturers are the backbone of educational activities especially those related to the activities of the teaching and learning process. Without the role of the lecturer, the teaching and learning process will be disrupted and even fail. Therefore, in the management of education the role of lecturers in the effort to succeed in education is always improved, the performance or work performance of lecturers must always be improved given the challenges of the world of education to produce quality human resources that are able to compete in the global era.

Technological advancements and changes have given new awareness that Indonesia is no longer standing alone. Indonesia is in the midst of a new world, an open world so people are free to compare life with other countries. To be able to stand in line with other countries, Indonesia needs high-quality and highly competitive human resources. Education is a pillar in increasing human resources for nation building. Therefore, we should be able to improve Indonesia's human resources which are not less competitive with human resources in other 
countries. Improving the quality of human resources can be met through improving the quality of education in Indonesia by implementing effective education.

Effective education is an education that allows students to be able to learn easily, pleasantly and achieve goals as expected. Lecturers have a very important role in increasing the effectiveness of learning in order to achieve effective education. In the sense that lecturers as one of the learning agents serves to improve the quality of education in higher education. To be able to carry out their functions properly, lecturers must have certain conditions, one of which is competence. With these competencies, lecturers are expected to create effective education in order to improve the quality of education [2].

The problem of the effectiveness of education is closely related to the comparison between the level of achievement of goals and plans that have been prepared beforehand. An organization is declared effective if the goals of organizational members and organizational goals are achieved according to or above the set target. In Law Number 20 of 2003 concerning the National Education System it is stated that national education functions to develop capabilities and form a dignified nature and civilization of the nation in order to educate the life of the nation. It was also stated that education is aimed at developing the potential of students to become human beings who believe and believe in the One God, noble, healthy, knowledgeable, capable, creative, independent, and become citizens who are democratic and responsible [3].

The obligation of lecturers is no longer limited to teaching, researching, and serving, but comes to campus every day. This "new" policy is considered to cause controversy among lecturers. The lecturer's first red report card was the lack of teaching attendance in the class (less than 16 meetings), even though only a small number of lecturers. The lecturer met the students once in one semester, it was just a sign of the card from the student's study. The guidance model is often difficult, namely the thesis is placed in the lecturer drawer, the lecturer corrects it, then the student takes the results. Ideally, guidance will be conducted faceto-face so that students can ask questions or be given direct direction. The fourth red report of the lecturer is the death of the consortium of lecturers. The lecturers who are members of the consortium in their respective study programs did not conduct intensive discussions, both deepening their knowledge, learning methods, and research grand design. Every time the lecturer discussion is held, less than 50 percent attend. Gathering lecturers for a discussion will not be an obstacle if the lecturer is required to go to campus every day.

The five lecturers, red report cards were less enthusiastic in attending seminars, workshops, and public lectures. The activities that should be lecturers as the main audience are actually attended by students. The contribution of lecturers is getting smaller, especially in the call for papers that are disseminated. Therefore, the number of seminars and workshops on a campus does not automatically affect the improvement of lecturer competencies on the campus. In fact, every seminar and workshop activity at the level of study programs, faculties, and universities is definitely aimed at improving the competence of lecturers [4].

At the Trisakti Jakarta Transportation and Logistics Institute, the effectiveness of lecturers' work still needs to be improved. In this regard, he hopes that every lecturer at the Trisakti Institute of Transportation and Logistics should improve his competence and ability to teach and work. The quality of lecturers clearly has a big influence on the effectiveness of lecturers' work. Qualified lecturers will try to carry out their duties as well as possible in achieving educational goals. Qualified lecturers will not work carelessly in educating students, printing quality and competitive resources. Learning on campus is not only a formality of the formation of human resources, because lecturers will carry out their duties in accordance with existing provisions. 
Effectiveness is not only goal oriented, but also in the process of achieving the goal itself. In the world of education, the process carried out in achieving goals is the learning process, so that effectiveness can be interpreted as the ability of an institution to implement planned learning programs and the ability to achieve the results and objectives that have been set. Education is a process in order to influence students to be able to adjust as well as possible to their environment and thus will cause changes in themselves that allow them to function in society. The process of influencing these students takes place in the classroom. According to Seyfarth "the model is assumes that student learning is directly related to teacher's classroom behavior. That behavior is influenced by: (1) teacher's knowledge of effective teaching techniques, the subject they teach, and appropriate ways of motivating students; (2) teacher's motivation to perform effectively on the job; and (3) availability of support services to enhance teachers and students efforts [5] From Seyfarth statement, it can be translated that, lecturer behavior in the classroom is influenced by: (1) lecturer knowledge about effective teaching techniques, subjects they teach, and appropriate ways to motivate students, (2) motivation of lecturers to carry out the process effective learning, and (3) availability of support services, facilities and infrastructure to improve lecturers and student efforts.

The main task of a lecturer is to organize the teaching and learning process in the classroom. Thus the effectiveness of lecturer work in the classroom is absolutely necessary which is based on high dedication. Work effectiveness is very important, because it is closely related to the smoothness of the process of lecture activities and is the point of success of students in achieving achievement in learning, therefore the effectiveness in carrying out tasks will have a direct impact on student behavior. It does not rule out the possibility that the failure of the teaching program and the low student learning outcomes on campus are caused by the low effectiveness of lecturers' work in carrying out their duties as instructors.

Effectiveness is the extent to which an action or idea leads to the desired state or outcome. The word effectiveness which basically means doing or doing something right. While work, can be interpreted as an activity of doing something that is done (done), so work effectiveness is a successful activity. A job can be said to be effective if the purpose of the work can be achieved in accordance with what was previously planned. A person can work well so he can be said to work effectively. In the implementation of work always use five business sources, namely mind, energy, time, money, and things. Although the different combinations for each type of work in general, people doing certain activities want maximum results [6].

Thus work effectiveness is the achievement of work goals through activities carried out based on indicators: the accuracy of the process of completing a job, evaluating how to complete the work, the success of making decisions, completing work in a timely manner, achieving set goals and utilizing resources appropriately [7].

Stephen. P. Robbins states the effect of self-efficacy on work effectiveness as, "Self efficacy can create positive spheres in which those with high efficacy become more engaged in the task and then, in turn, increase performance, which increase efficacy further [8] Changes in self-efficacy over time is related to changes in creative performance as well. Individuals high in self-efficacy also seem to respond to negative feedback with effort, while those who are low in self-efficacy are likely to be less interested in their efforts. Self-efficacy will have a positive impact to be a high level of belief that is related to the task and obligation to improve performance which is then to increase self-confidence later

Self-efficacy is self-efficacy is a person's inner belief about the ability and competence to carry out tasks to be successful based on indicators: efforts to complete work, efforts to achieve success, perseverance in carrying out work, efforts to change oneself based on experience [9]. 
Debora L. Nelson states the effect of work design on work effectiveness as follows, "although research investigating these five aspects of team job design is limited, preliminary findings are somewhat promising. [10] The extensive after work of effective work groups, one set of researchers studied for work, the work group productivity, group member satisfaction, and managers, judgments of group effectiveness. It was explained that job design has an effect on effectiveness, both the effectiveness of group work, membership satisfaction, and manager decisions that are part of the effectiveness of a team or group. Job design is a work design that is designed to regulate work assignments in fulfilling job needs and fulfillment of achievement of objectives with indicators: application of methods in completing work, choosing the type of work according to ability, selection of procedures in work, work rotation, expansion of work, and work enrichment [11] Jennifer M. George, Gereth R. Jones states the influence of work motivation on work effectiveness: "When employees are motivated to contribute inputs at a high level (to work harder, more efficient, and more creatively) and perform their jobs more effectively, organizational effectiveness increases ". [12] Lecturers are motivated to work harder, more efficiently, more creatively, and more effectively, in order to improve work effectiveness in the organization. Furthermore, according to Chuck Williams suggested that, "the primary goal of the model is to create positive personal and work outcomes such as internal work motivation, satisfaction which one 's job, and work effectiveness". The main purpose of this model is internal motivation to work to create jobs that produce personal results and positive work like us, satisfaction with one's work, and work effectiveness. This can be interpreted if the lecturer has a high level of work motivation, the lecturer will carry out maximum work actions in achieving goals, so that the work effectiveness is higher [13].

Work motivation is an impulse that arises in a person who moves and directs his behavior to carry out work in achieving predetermined goals with indicators: goal-oriented, seriousness in work, needs for achievement, effort to progress, enthusiasm in work. In general, this study aims to determine the description of the presence or absence of influence between variables; (1) positive direct effect of self-efficacy on work effectiveness, (2) positive direct effect of work design on work effectiveness, (3) positive direct effect of work motivation on work effectiveness, (4) positive direct effect between self-efficacy on work motivation, (5) positive direct effect of work design on work motivation. [14]

\section{Research Methods}

\subsection{Location}

This quantitative research uses a survey method through the Path Analysis approach. The instrument used in all variables in the form of questionnaires. Before being used in the study, an instrument trial was conducted to test the validation and rehabilitation of each instrument so that it could be used in the study. The study was conducted on 93 lecturers at the Trisakti Jakarta Transportation and Logistics Institute. The number of lecturers is 122 lecturers and sampling using the Slovin formula. A sample of 93 lecturers was obtained by a simple random method from the population and spread in the Trisakti ITL Jakarta.

\subsection{Procedure}

The data in this study were collected using instruments in the form of questionnaires which included questionnaires on work effectiveness, self-efficacy, work design and work motivation, which had passed the stages of empirical validation through instrument testing. Furthermore, the calculation of reliability is carried out on a valid instrument item that shows 
the feasibility of the instrument to be used in the study. The results of the validation test and calculation of instrument reliability are as follows: (1) work effectiveness questionnaire, validation $=94.28 \%$, reliability $=0.949$, (2) self-efficacy questionnaire, validation $=88.57 \%$, reliability $=0.948$, (3) questionnaire work design, validation $=88.57 \%$, reliability $=0.957$, (4) work motivation questionnaire, validation $=91.43 \%$, reliability $=0.946$. So it is concluded that all valid instrument items are reliable instruments.

The research data analysis technique was analyzed using descriptive analysis and inferential analysis with a path analysis approach. Descriptive analysis is done by calculating the average, median, mode, variance, and standard deviation values.

Before path analysis was carried out, the researcher determined the regression equation between variables: (1) $\widehat{X}_{4}=27,005+0,808 X_{1}$, (2) $\widehat{X}_{4}=54,638+0,565 X_{2}$, (3) $\widehat{X}_{4}=37,236+$ $0,701 \mathrm{X}_{3}$, (4) $\widehat{\mathrm{X}}_{3}=42,376+0,671 \mathrm{X}_{1},(5) \widehat{\mathrm{X}}_{3}=53,386+0,568 \mathrm{X}_{2}$. In order for regression analysis to be carried out, then testing requirements is a must. Data analysis to test the research hypothesis was carried out by statistical analysis or path analysis. Before testing hypotheses, an analysis of the requirements test is first performed which includes the following: (1) test the estimated error normality, and (2) test the significance and regression linearity.

The estimated error normality test using the lilliefors test. The testing criteria is if L.count $<$ L.table at $\alpha=0.05$, the regression equation is normally distributed. Based on the calculation results of the X4 estimation error test for X1, X4 over X2, X4 over X3, X3 over $\mathrm{X} 1, \mathrm{X} 3$ over $\mathrm{X} 2$, all of them indicate that L.count < L.table so that all regression equations are normally distributed.

For the significance test carried out by calculating ANAVA with the testing criteria is if $F$ count $>F$ table at $\alpha=0.01$ then the regression coefficient between variables is significant. Based on the results of the calculation of the $\mathrm{X} 4$ significance test on $\mathrm{X} 1, \mathrm{X} 4$ on $\mathrm{X} 2, \mathrm{X} 4$ on $\mathrm{X} 3$, $\mathrm{X} 3$ on $\mathrm{X} 1$, and $\mathrm{X} 3$ on $\mathrm{X} 2$, all of them indicate that $\mathrm{F}$ count $>\mathrm{F}$ table, the regression coefficient between all variables is very significant.

To test the linearity of a simple regression equation with the criteria that if $\mathrm{F}$ count $<\mathrm{F}$ table then the relationship between variables is linear. Based on the results of the calculation of the linearity test X4 over X1, X4 over X2, X4 over X3, X3 over X1, X3 over X2, all of them show that $\mathrm{F}$ count $<\mathrm{F}$ table then all relationships between variables are linear.

After testing the estimated error normality, test the significance and linearity of the regression, then the path analysis is performed to test the research hypothesis. The following table describes the results of the calculation and testing of the path coefficient with $t$ table = 1.662 for $\alpha=0.05$ with the criteria if $t$ count $>$ from $t$ table then the results of the path coefficient test indicate that the path is very good and can explain the influence between variables

Table 1. Results and Path Coefficient Testing

\begin{tabular}{lccc}
\hline Path & $\begin{array}{c}\text { Coefficient } \\
\text { Correlation }\end{array}$ & $\begin{array}{c}\text { Coefficient of } \\
\text { Path }\end{array}$ & $\mathrm{t}_{\text {count }}$ \\
\hline $\mathrm{X}_{1}$ on $\mathrm{X}_{4}$ & $\mathrm{r}_{14}=0,658$ & $\mathrm{p}_{41}=0,465$ & 4,747 \\
$\mathrm{X}_{2}$ on $\mathrm{X}_{4}$ & $\mathrm{r}_{24}=0,447$ & $\mathrm{p}_{42}=0,169$ & 1,908 \\
$\mathrm{X}_{3}$ on $\mathrm{X}_{4}$ & $\mathrm{r}_{34}=0,593$ & $\mathrm{p}_{43}=0,202$ & 1,880 \\
$\mathrm{X}_{1}$ on $\mathrm{X}_{3}$ & $\mathrm{r}_{13}=0,646$ & $\mathrm{p}_{31}=0,521$ & 6,618 \\
$\mathrm{X}_{2}$ on $\mathrm{X}_{3}$ & $\mathrm{r}_{23}=0,532$ & $\mathrm{p}_{32}=0,341$ & 4,330 \\
\hline
\end{tabular}


Thus it can be concluded that the path between the variables of self-efficacy on work effectiveness, work design on work effectiveness, and work motivation on work effectiveness, self-efficacy on work motivation, and work design on work motivation, the path coefficient is significant because $t$ count $>$ from $t$ table. The path coefficient test results in this study indicate that the paths are very well shaped and can explain the influence of self-efficacy, work design, and work motivation on the effectiveness of the work of the Trisakti Institute of Transportation and Logistics Jakarta. So that it can explain the influence of exogenous variables with endogenous variables analyzed.

The results of the study mean that in general the lecturers of the Trisakti Jakarta Institute of Transportation and Logistics have five positive direct effects: (1) self-efficacy on work effectiveness, (2) work design on work effectiveness, (3) work motivation on work effectiveness, (4) self-efficacy on work motivation, (5) work design on work motivation. In detail the discussion of the results of the analysis and testing of the research hypothesis is described as follows:

\subsection{Effect of Self Efficacy on Work Effectiveness}

To prove self-efficacy has a positive direct effect on work effectiveness, the statistical hypothesis is: $\mathrm{H} 0: \beta 41 \leq 0, \mathrm{H1}: \beta 41>0$. The results of the calculation of the effect of work self-efficacy on work effectiveness, obtained path coefficient of 0.465 and $t$ count of this path coefficient of $4,747, \mathrm{t}$ count $(4,747)>\mathrm{t}$ table $(2,368)$ at $\alpha=0,01$, then $\mathrm{H} 0$ is rejected. It can be concluded that there is a positive direct effect of self-efficacy on work effectiveness. That is, increasing self-efficacy will result in increased work effectiveness.

By referring to the relevant outcome findings and / or theory. P. Robbins states the effect of self-efficacy on work effectiveness as: Self-efficacy can create a positive spiral in which those with high efficacy become more engaged in their task and then, in turn, increase performance, which increase efficacy father. Changes in self-efficacy over time are related to changes in creative performance as well. Individuals high in self-efficacy also seem to respond to negative feedback with increased effort in motivation, while those low in self-efficacy are likely to lessen their effort after negative feedback [14].

The results showed that self-efficacy had an effect on work effectiveness, it could be interpreted that the self-efficacy possessed by lecturers led to an increase in the effectiveness of the lecturers of the Trisakti Jakarta Transportation and Logistics Institute. Based on this empirical evidence, it is said that this finding shows that self-efficacy is one of the variables that has a direct effect on the variable work effectiveness. Self-efficacy will influence the increasing effectiveness of work for lecturers.

\subsection{Effect of Job Design on Work Effectiveness}

To prove the work design has a positive direct effect on work effectiveness, the statistical hypothesis is: $\mathrm{H} 0: \beta 42 \leq 0, \mathrm{H} 1: \beta 42>0$. The results of the calculation of the effect of work design on work effectiveness, obtained path coefficient of 0.169 and count of this path coefficient of $1.908, \mathrm{t}$ count $(1,908)>\mathrm{t}$ table $(1,662)$ at $\alpha=0,05$, then $\mathrm{H} 0$ is rejected. Thus it is concluded that there is a positive direct effect of work design on work effectiveness.

By referring to the relevant outcome findings and / or theory Debora L. Nelson states the influence of work design on work effectiveness as follows: Although research investigating these five aspects of team job design is limited, preliminary findings are somewhat promising. After an extensive review of the literature on effective work groups, one set of 
researchers studied the degree to which works group job design could affect such important effectiveness outcomes as work group productivity, group member satisfaction, and managers, judgments of group effectiveness [15].

The results of the study show that work design influences work effectiveness, meaning that good work design will lead to increased effectiveness of the work of the Trisakti Jakarta Institute of Transportation and Logistics Institute. Based on this empirical evidence, it is said that this finding shows that work design is one of the variables that has a direct effect on the variable work effectiveness. A good work design will affect the increasing effectiveness of work for lecturers.

\subsection{Effect of Work Motivation on Work Effectiveness}

To prove work motivation has a positive direct effect on work effectiveness, the statistical hypothesis is: H0: $\beta 43 \leq 0, \mathrm{H} 1: \beta 43>0$. The results of the calculation of the effect of work motivation on work effectiveness, obtained path coefficient of 0.202 and $t$ count of this path coefficient of $1.880, \mathrm{t}_{\text {count }}(1,880)>\mathrm{t}$ table $(1,662)$ at $\alpha=0,05$, then $\mathrm{H} 0$ is rejected. Thus it is concluded that there is a positive direct effect of work motivation on work effectiveness.

By referring to the relevant outcome findings and / or theory Jennifer M. George, Gereth R. Jones states the effect of work motivation on work effectiveness: "When employees are motivated to contribute inputs at a high level (to work harder, more efficiently, and more creatively) and perform their jobs more effectively, organizational effectiveness increases"'[16].

The results showed that work motivation had an effect on work effectiveness, it could be interpreted that the decrease in work motivation felt by lecturers would lead to increased effectiveness of the lecturers of the Trisakti Jakarta Transportation and Logistics Institute. Based on this empirical evidence, it is said that this finding shows that work motivation is one of the variables that has a direct effect on the variable work effectiveness. high work motivation will affect the increasing effectiveness of work for lecturers.

\subsection{Effect of Self Efficacy on Work Motivation}

To prove self-efficacy has a direct positive effect on work motivation, the statistical hypothesis is: H0: $\beta 31 \leq 0, \mathrm{H1}: \beta 41>0$. The results of the calculation of the effect of selfefficacy on work motivation, obtained path coefficient of 0.521 and $t_{\text {count }}$ of this path coefficient of $6.618, \mathrm{t}_{\text {count }}(6.618)<\mathrm{t}$ table $(2,359)$ at $\alpha=0.01$, then $\mathrm{H} 0$ is rejected. Thus it was concluded that there was a positive direct effect of self-efficacy on work motivation.

By referring to the relevant outcome findings and/or theory Luthans stated the influence of work design on work motivation:

In others words, from the preceding it can be seen that self-efficacy can directly affect: choice behaviors, decisions will be made based on how efficacious the person feels toward the option in, say, work assignments or even a career field; motivational effort, people will try harder and give more effort on tasks where they have high self-efficacy than those where the efficacy judgment is low; perseverance, those with high self-efficacy will bounce back, be resilient when meeting problems or even failure, where as those with low self-efficacy tend to give up when obstacles appear [17].

Proper self-efficacy will have an impact on increasing work motivation on the lecturer. The results showed that self-efficacy had an effect on work motivation, it could be interpreted that the good self-efficacy possessed by lecturers would lead to an increase in the work motivation of the Trisakti Institute of Transportation and Logistics Jakarta. Based on this 
empirical evidence, it is said that these findings indicate that self-efficacy is one of the variables that directly affects work motivation variables

\subsection{Effect of Job Design on Work Motivation}

To prove the work design has a positive direct effect on work motivation, the statistical hypothesis is: $\mathrm{H} 0$ : $\beta 32 \leq 0, \mathrm{H} 1: \beta 42>0$. The results of the calculation of the effect of work design on work motivation, the path coefficient is 0.341 and the $t_{\text {count }}$ of this path coefficient is $4,330, \mathrm{t}$ count $(4,330)<\mathrm{t}$ table $(2,359)$ at $\alpha=0,01$, then $\mathrm{H} 0$ is rejected. Thus it is concluded that there is a positive direct effect of work design on work motivation.

By referring to the relevant outcome findings and/or theory Jampoux states the influence of work design on work motivation as follows, "the design of job can strongly effect a person's motivation and satisfaction [18].

The results showed that work design had an effect on work motivation, it could be interpreted that good work design would lead to an increase in the motivation of the work of the Trisakti Institute of Transportation and Logistics Jakarta. Based on this empirical evidence, it is said that this finding shows that work design is one of the variables that directly influences work motivation variables. A good work design will affect the increase in work motivation on the lecturer.

\section{Conclusion}

Based on the results of testing hypotheses and discussing the results of the research presented in the previous chapter, the research conclusions as follows: (1) Self-efficacy has a positive direct effect on the effectiveness of the dossiers of the Trisakti Institute of Transportation and Logistics Jakarta. This means that increasing self-efficacy will lead to increased work effectiveness; (2) Job design has a direct positive effect on the effectiveness of the work of lecturers at the Trisakti Jakarta Institute of Transportation and Logistics. The meaning of accurate job design improvement will lead to a high increase in work effectiveness; (3) Work motivation has a positive direct effect on the effectiveness of the work of lecturers at the Trisakti Jakarta Transportation and Logistics Institute. This means that a high increase in work motivation will cause a high increase in work effectiveness; (4) Selfefficacy has a positive direct effect on the work motivation of lecturers at the Trisakti Jakarta Institute of Transportation and Logistics, which means that high self-efficacy will cause a high increase in work motivation; (5) Job design has a direct positive effect on work motivation and in the Trisakti Institute of Transportation and Logistics Jakarta. This means that an accurate increase in work design will lead to an increase in high work motivation.

Based on the research findings above, it can be stated that work effectiveness can be influenced by variables of self-efficacy, job design, and work motivation. However, other variables still need to be considered in further research related to work effectiveness variables. Efforts to improve self-efficacy, work design, and increase the work motivation of lecturers as a consequence of research conclusions, the following should be done

\subsection{Efforts to Improve Self Efficacy}

The results of the study indicate that there is a direct positive effect between self-efficacy and the work effectiveness of lecturers. Efforts that can be made in improving self-efficacy are: (a) Lecturers need to have confidence in their efforts to be able to complete a job; (b) Lecturers need to have efforts to achieve success in every responsibility that has been entrusted by superiors; (c) Lecturers need to have perseverance in controlling time in work 
based on the suitability and ability of lecturers on the field of work to be given; (d) Lecturers take part in work in accordance with their parts, but lecturers can help other lecturers and lecturers in completing work. The boss needs to also control the work of a lecturer so that it is not too late in carrying out the work; (e) Lecturers need to have an attitude to learn from past experience that can provide an overview of strategies in carrying out work well; (f) Lecturers need to determine work planning in carrying out their duties, so that goals are achieved properly.

\subsection{Efforts to Improve Job Design}

The results of the study show that there is a direct positive effect between job design and the effectiveness of lecturers' work. Efforts that can be made in improving work effectiveness are: (a) Bosses need to distribute the tasks evenly in accordance with the workload that is in accordance with their abilities; (b) In determining the method of work, a lecturer needs to pay attention in terms of time, cost and effectiveness and work efficiency; (c) Bosses need to consider in carrying out work rotation which consists of shifting work and developing skills. This effort can be carried out, among others, by providing opportunities for lecturers to rotate in their work in turns and periodically according to the specified time; (d) Bosses need to provide expansion of work consisting of variations in tasks and work challenges. This effort can be carried out by giving new jobs that are challenging, giving direction and solutions to lecturers who experience problems in work, and provide a variety of tasks according to needs; (e) Bosses need to provide work enrichment consisting of autonomy and responsibility. good work facilities, involve lecturers in compiling work programs and introducing relevant work methods.

\subsection{Efforts to Decrease Work Motivation}

The results of the study show that there is a direct negative influence between work motivation and the work effectiveness of lecturers. Efforts that can be made in increasing trust are as follows: (a) Lecturers need to have an orientation to the objectives in carrying out the tasks; (b) Lecturers need to have seriousness in carrying out work, in terms of working time always on time; (c) Lecturers need to be aware of the work given by the superior as a responsibility as a lecturer so that the work can be done well; (d) Lecturers need to have confidence that work is a need for achievement. By carrying out work in accordance with regulations; (e) Lecturers need to get an increase in the intensity of guidance and direction by supervisors at regular intervals; (f) Lecturers need to do work enthusiastically, so that the results obtained will be satisfactory.

Acknowledgements. The authors gratefully acknowledge that the present research is supported by Transportation and Logistic Institute Trisakti Jakarta .

\section{References}

[1] Wood, William B. and Kimberly D. Tanner. The Role of the Lecturer as Tutor: Doing What Effective Tutors Do in a Large Lecture Class. Journal List CBE Life Sci Educ v.11(1); doi: 10.1187/cbe.11-12-0110.

[2] Usman, Husaini, (2010). Manajemen : Teori, Praktik, dan Riset Pendidikan (Management: Theory, Practice, and Educational Research), Jakarta: Bumi aksara. 
[3] Undang-Undang Republik Indonesia Nomor 20 Tahun 2003 tentang Sistem Pendidikan Nasional pasal 3 (Law of the Republic of Indonesia Number 20 of 2003 concerning Article 3 of the National Education System)

[4] Musfah, Jejen, http://www.republika.co.id/berita/koran/opini-koran/era baru/kewajiban/dosen (news / newspaper /(new era obligation lecturer) 15/07/11.

[5] Seyfarth, John T., (2002). Human Resources Management for Effective Schools United State: Allyn and Bacon.

[6] De Janasz, Suzanne C., at all, (2009). Interpersonal Skills in Organizations, New York: McGraw-Hill

[7] K, Yaman (2015). Self-Efficacy and Academic Achievement, Journal of Education and Practice, Vol. 6, No. 29.

[8] Robbins, Stephen P. Timothy A. Judge, (2009). Organizational Behavior, New York: Pearson Prentice Hall.

[9] Robbins, Stephen, Timothy A, Judge, (2011). Organizational Behavior, New Jersey: Pearson.

[10] Nelson, Debra L. (2006). Organizational Behavior, USA Thomson South-Western.

[11] Luthans, Fred, (2011). Organization Behavior, An Evidence Based Approach, New York: Mc Graw Hill Irwin.

[12] George, Jenniffer M. Gareth R. Jones, (2012). Understanding and Managing Organizational Behavior, New Jersey: Pearson.

[13] A.B, Shani, (2009). Behavior In Organizations, An Experience Approach, Ninth Edition, New York, McGraw-Hill.

[14] Daft, Richard L. (2012). New Era of Management, United State: South Western Cengage Learning.

[15] Stephen P. Robbins, Thimoty A. Judge (2013), Organizational Behavior, Fifteen Edition 2013.

[16] Debra L. Nelson (2006), Organizational Behavior. USA Thomson South-Western.

[17] Jennifer M. George, Gereth R. Jones (2012), Understanding and Managing Organizational Behaviour, Sixth Edition. New Jersey: Upper Saddle River.

[18] Fred Luthans (2011), Organization Behavior, An Evidence Based Approach. New York: McGraw- Hill Irwin. 